\title{
Level of Dietary Diversity and Associated Factors among Adult Patients on HAART at Public Health Facilities of Ambo town, West Shoa Zone Ethiopia
}

\author{
Kefyalew Taye", Diriba Alemayehu, Esayas Tadesse, Takele Tiki \\ Ambo University College of Medicine and Health Sciences, Ambo, Ethiopia
}

\begin{abstract}
Background: Nutrition and HIV are strongly related to each other, any immune impairment as a result of HIV/ AIDS leads to malnutrition, and malnutrition leads to immune impairment. HIV infected patients are at nutritional risk at any time of their illness. In developing countries HIV/AIDS, food insecurity and malnutrition are common. Dietary diversity scores have been positively correlated with increased micronutrient adequacy of diet in adults. Thus this study aims to assess level dietary diversity and associated factors among Adults on HAART at Public Health facilities of Ambo town.

Methods and Materials: The study was conducted at Ambo Town, West Shoa Zone Ethiopia. A facility-based crosssectional study was conducted from January 26-February 26, 2019. A total of 313 study participants were included in the study. Systematic random sampling technique was applied to reach the study subjects. A structured questionnaire which included socio-demographic and health-related factors were prepared based on objectives of the study after reviewing different kinds of literature. Questionnaires on Dietary diversity were adopted from FAO 2010. Data were coded and entered to Epi-data version 3.1 and exported to SPSS version 21 for analyses. Frequency, mean and standard deviations from descriptive statistics and analytic statistics such as bivariate and multivariable logistic regression analysis were computed to determine the effect of various factors on the outcome variable.

Result: In this study, 310 HIV positive adults on HAART follow up at Public health facilities of Ambo town were participated in the study making a response rate of $99 \%$. This study shows $71 \%$ of adults had low individual dietary diversity score. It was noticed that HIV positive Males were $57 \%$ less likely to have low dietary diversity than females (AOR at $95 \% \mathrm{CI}=0.43(0.21-0.87)$. Adult patients those who were separated from their husband/wife were about $68 \%$ less likely to have low dietary diversity than widowed HIV positive adults (AOR at 95\% CI=0.32 (0.11-0.88). Monthly income was also seen to be the factors significantly associated with dietary diversity.

Conclusion and Recommendation: This study revealed that about $71 \%$ of adult patients on HAART had low dietary diversity score which indicates severe nutrient inadequacy among the study participants. Therefore the town administration, NGO's working on HIV and other stakeholders should work on empowering females and sustainable income generating projects for HIV patients.

Keywords: Dietary diversity; Ethiopia; HIV/AIDS

Acronyms and Abbreviations: ART: Anti Retro Viral Therapy; BMI: Body Mass Index; EPHI: Ethiopian Public Health Institute; FAO: Food and Agricultural Organization of United Nation; HAART: Highly Active Antiretroviral Therapy;HIV: Human Immunodeficiency Virus; : Individual Dietary Diversity Score; MOH: Ministry of Health;
\end{abstract}

Corresponding author: Kefyalew Taye, College of Medicine and Health Sciences, Ambo University, Ethiopia, E-mail: kefyalewtaye24@gmail.com Received date: June 21, 2019; Accepted date: July 12, 2019; Published date: July 22, 2019

Citation: Taye K, Alemayehu D, Tadesse E, Tiki T (2019) Level of Dietary Diversity and Associated Factors among Adult Patients on HAART at Public Health Facilities of Ambo town, West Shoa Zone, Ethiopia. J Trop Dis 7:324.

Copyright: (C) 2019 Taye K, et al. This is an open-access article distributed under the terms of the Creative Commons Attribution License, which permits unrestricted use, distribution and reproduction in any medium, provided the original author and source are credited. 
PLWHA: People Living with HIV/AIDS; SPSS: Statistical Package for Social Sciences; USAID: United State Agency for International Development; WFP: World Food Program

\section{INTRODUCTION}

HIV prevalence is increasing worldwide because people on antiretroviral therapy are living longer, although new infections decreased from 3.3 million in 2002, to 2.3 million in 2012. Global AIDS-related deaths peaked at 2.3 million in 2005 and decreased to 1.6 million by 2012. An estimated 9.7 million people in low-income and middle-income countries had started antiretroviral therapy by 2012 [1]. SubSaharan Africa has been devastated by the HIV/AIDS epidemic. While only $10 \%$ of the world's population lives in sub-Saharan Africa, an estimated $70 \%$ of all HIV infected adults and children are found here [2]. According to the most recent UNAIDS estimates, $71 \%$ of the estimated 2.1 million Adults live with HIV in 2016 lived in just 10 high-burden countries, including nine in Sub-Saharan Africa and India [3]. In Ethiopia, there are over 718,550 people living with HIV, about $1.2 \%$ of the total population of the country. In addition, about $34 \%$ of young adult's deaths and 632,670 orphanages were due to HIV/ AIDS [4,5].

HIV was found to affect nutritional status by increasing energy requirements, reducing food intake, and adversely affecting nutrient absorption and metabolism [6]. Failing to meet nutritional needs may lead to decreased immunity and increased susceptibility to opportunistic infections (OIs), which can lead to further malnutrition [7]. Additionally, nutrient intake can improve antiretroviral absorption and tolerance. Receiving appropriate nutrition can help improve PLHIV's quality of life. Poor nutritional status in PLHIV speeds the disease progression, increases morbidity, and reduces survival time [8]

Dietary diversity is a qualitative measure of food consumption that reflects household access to a wide variety of food and is also a proxy of the nutritional adequacy of an individual's diet [9-11]. The IDDS aims to capture nutritional adequacy and many studies amongst people of different age groups have shown that its increase is related to increased nutrient adequacy of the diet [12]. Dietary diversity scores have been positively correlated with increased mean micronutrient density adequacy of complementary foods and micronutrient adequacy of the diet in adults [13].

Even then there is a complex interaction between dietary diversity/intake, immune function, and HIV/AIDS and malnutrition. Few studies have been conducted regarding this significant public health problem throughout the country. Therefore, the aim of this study was to assess the level of dietary diversity and associated factors among HIV positive adults attending ART clinics at Ambo town Public health facilities, West Shoa Zone, Ethiopia.

\section{METHODS AND MATERIAL}

\section{Study area and design}

The study was conducted in Ambo Town, West Shoa Zone, Oromia regional state, Ethiopia. Ambo town is found at $110 \mathrm{Km}$ to the West direction of Addis Ababa Capital city of Ethiopia. The town covers a total area of 3025 square kilometers and altitude of 2169 meter above sea level, with Woinadega type of climatic condition. There are four public health facilities which provide ART service in the town, namely Award Health Center, Ambo Health Center, Ambo General Hospital, and Ambo University Referral Hospital. During the study period of this work, there were 3006, 215, 54 and 43 ART attendants at Ambo General Hospital, Ambo Health Center, Ambo University Referral Hospital and Award Health Center respectively. The study was conducted from January, 26-February, 26/2019. The institution-based cross-sectional study design was used in this study.

\section{Study populations and sample size}

All adults on HAART at public health facilities of Ambo town are source population. All randomly selected adults on HAART are included in this study. The following assumptions were considered while calculating the sample size. Ninety-five percent confidence level (CI=95\%), $\mathrm{p}=28.7 \%$ representing the prevalence estimates of adult low dietary diversity on HAART [14], $10 \%$ on response rate. Finally, the sample size is calculated using the single population formula.

$n=\frac{(Z \alpha / 2)^{2}(P)(1-p)}{d^{2}}=\frac{(1.96)^{2}(0.287)(1-0.287)}{0.05^{2}}=314$

Hence the estimated population size is less than 10,000 (i,e there were only about 3,318 patients who are attending ART clinics at Ambo Town), using the following correction formula $n f=\frac{n i}{1+n i / N}=\frac{314}{1+314 / 3318}=284$

Finally adding 10\% nonresponse rate, the final sample size becomes 313 .

\section{Sampling technique and data collection}

First study subjects are allocated to each institution proportion to the patient load. Then systematic random sampling technique was applied using a registration card as a frame to select the eligible study subjects. A structured questionnaire which included socio-demographic and health-related factors were prepared based on objectives of the study after reviewing different kinds of literature. Questionnaires on Dietary diversity were adopted from FAO 2010. Finally, the questionnaire was translated into the local language to facilitate the data collection process. 


\section{Measurements of dietary diversity}

Individual dietary diversity scores indicate nutrient adequacy. Studies in different age groups have shown that an increase in individual dietary diversity score is related to increased nutrient adequacy of the diet. Dietary diversity scores have been validated for several age-sex groups as proxy measures for macro and micronutrient adequacy of diet [12-16]. Determination of the dietary diversity score of the respondents was completed primarily by listing all food items consumed by respondents (both in and out of home). Based on the Food and Agriculture Organization $(F A O, 2010)$ recommendation, foods eaten by the respondents were classified into 9 food groups: Starchy staples, dark leafy green vegetables, other vitamin A rich fruits and vegetables, other fruits and vegetables, organ meat, meat and fish, eggs, legumes, nuts and seeds, milk and dairy products. Participants received 1 point if they consumed at least once during the last 24 hours any of the foods within each subgroup, and 0 points if they never consumed the food. The IDDS was calculated as the sum of food groups consumed over 24 hours. The total individual food scores were first categorized into two categories, where $0-4$ were considered low dietary diversity scores and 5 or more food groups were considered high dietary diversity scores.

\section{Data processing and analysis}

Data were coded and entered to Epi-data version 3.1 and exported to SPSS version 21 for analyses. Frequency, mean and standard deviations from descriptive statistics and analytic statistics such as bivariate and multivariable logistic regression analysis were computed to determine the effect of various factors on the outcome variable. Variables having a p-value less than or equal to 0.05 on bivariate logistic regression were the candidate for multivariable logistic regressions. Statistical significance was declared at $p<0.05$. The strength of association between independent and dependent variables was assessed using the adjusted odds ratio with a $95 \%$ confidence interval.

\section{Ethical consideration}

Ethical clearance was received from the Ethical Review Committee of the College of Medicine and Health Sciences of Ambo University. Verbal consent was obtained from the study subjects after they had been informed about the objectives and procedures of the study.

\section{RESULTS}

\section{Socio-demographic characteristics}

In this study, 310 HIV positive adults on ART follow up at Public health facilities of Ambo town were participated in the study making a response rate of 99\%. Out of these, $201(64.8 \%)$ were females and the mean age of the respondents was 38.32 $(\mathrm{SD}= \pm 9.937)$. One hundred sixty-nine $(54.5 \%)$ participants were Orthodox Christians followers, 173 (55.8\%) were married and $133(42.9 \%)$ had completed their primary and secondary education. A majority of the respondents (77.4\%) source of food was obtained from the market by purchasing (Table 1).

Table 1: Socio-economic and demographic factors characteristics of patients on HAART at Public Health Facilities of Ambo town, West Shoa Zone, Ethiopia $2019(\mathrm{n}=310)$.

\begin{tabular}{|c|c|c|c|}
\hline Variable & Category & Frequency & Percent $\%$ \\
\hline \multirow[t]{2}{*}{ Sex } & Male & 109 & 35.2 \\
\hline & Female & 201 & 64.8 \\
\hline \multirow[t]{5}{*}{ Religion } & Orthodox & 169 & 54.5 \\
\hline & Muslim & 12 & 3.9 \\
\hline & Protestant & 120 & 38.7 \\
\hline & Catholic & 3 & 1.0 \\
\hline & Wakefata & 6 & 1.9 \\
\hline \multirow[t]{2}{*}{ Family size } & $<5$ people & 200 & 64.5 \\
\hline & $>=5$ people & 110 & 35.5 \\
\hline \multirow[t]{4}{*}{ Educational status } & $\begin{array}{l}\text { Not read and } \\
\text { write }\end{array}$ & 96 & 31 \\
\hline & $\begin{array}{l}\text { read and write } \\
\text { only }\end{array}$ & 66 & 21.3 \\
\hline & $\begin{array}{l}10 \text { and } 20 \\
\text { education }\end{array}$ & 133 & 42.9 \\
\hline & $\begin{array}{l}\text { College/ } \\
\text { University }\end{array}$ & 15 & 4.8 \\
\hline \multirow[t]{6}{*}{ Occupation } & Unemployed & 81 & 26.1 \\
\hline & $\begin{array}{l}\text { Government } \\
\text { employed }\end{array}$ & 34 & 11 \\
\hline & Merchant & 62 & 20 \\
\hline & Student & 20 & 6.5 \\
\hline & Farmer & 57 & 18.4 \\
\hline & Daily laborer & 56 & 18.1 \\
\hline \multirow[t]{4}{*}{ Marital status } & Married & 173 & 55.8 \\
\hline & Divorced & 60 & 19.4 \\
\hline & Single & 30 & 9.7 \\
\hline & widowed & 47 & 15.2 \\
\hline \multirow{2}{*}{$\begin{array}{l}\text { Owner of living } \\
\text { house }\end{array}$} & Rent & 141 & 45.5 \\
\hline & Private & 169 & 54.5 \\
\hline
\end{tabular}




\begin{tabular}{llll}
\hline \multirow{2}{*}{ Current residence } & Urban & 235 & 75.8 \\
\cline { 2 - 4 } & Rural & 75 & 24.2 \\
\hline Smoke cigarettes & Yes & 3 & 1 \\
\cline { 2 - 4 } & No & 307 & 99 \\
\hline Use of alcohol & Yes & 13 & 4.2 \\
\cline { 2 - 4 } & No & 297 & 95.8 \\
\hline Have a home & Yes & 50 & 16.1 \\
\cline { 2 - 4 } garden & No & 260 & 83.9 \\
\hline Time to go market & $<=30$ minute & 210 & 67.7 \\
\cline { 2 - 4 } & $>30$ minute & 100 & 32.3 \\
\hline $\begin{array}{l}\text { Who decides to buy } \\
\text { food for the family }\end{array}$ & \begin{tabular}{lll} 
Husband \\
\cline { 2 - 4 }
\end{tabular} & 100 & 32.3 \\
\cline { 2 - 4 } & wife & 193 & 62.3 \\
\cline { 2 - 4 } & $\begin{array}{l}\text { First son } \\
\text { member }\end{array}$ & 8 & 2.6 \\
\hline
\end{tabular}

\section{Measurements of dietary diversity of the study participants}

This study revealed that majorities, 220 (71\%), of the patients on HAART who were included in our study had low dietary diversity score (Figure 1). Most of them, 307 (99\%) consume starchy staples foods made of grains, roots, and tubers. Organ meats were the least $41(13.2 \%)$ consumed food by the study subjects (Table 2).

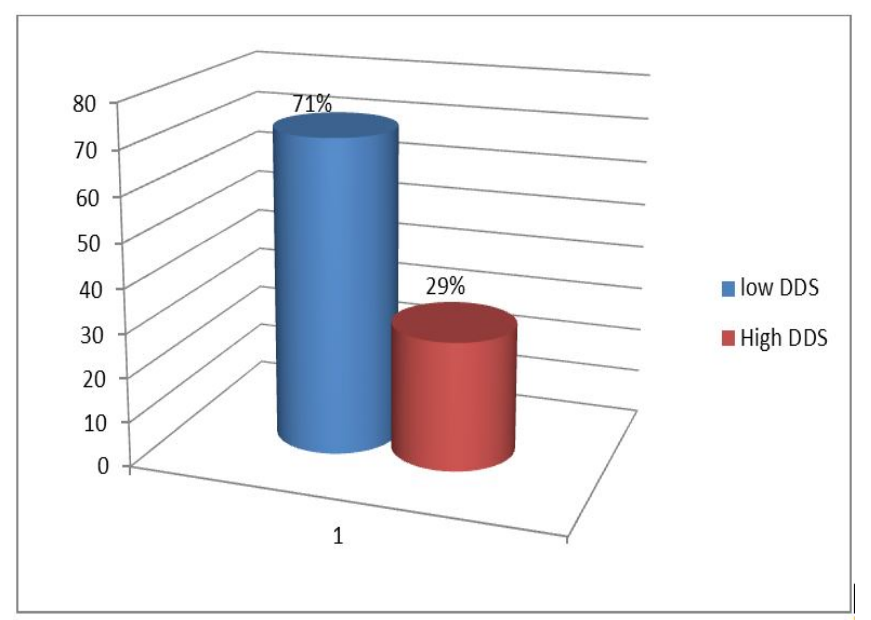

Figure 1: Dietary diversity score of patients on HAART at Public Health Facilities of Ambo town, West Shoa Zone, Ethiopia 2019 $(n=310)$.
Table 2: Food groups consumed by patients on HAART at Public Health Facilities of Ambo town, West Shoa Zone, Ethiopia 2019 $(n=310)$.

\begin{tabular}{lll}
\hline Food groups & Frequency (yes) & Percent \% \\
\hline Starchy staples & 307 & 99.0 \\
\hline Legumes, nuts, and seeds & 199 & 64.2 \\
\hline Organ meats & 41 & 13.2 \\
\hline Milk and dairy products & 56 & 18.1 \\
\hline Meat, and fish & 59 & 19.0 \\
\hline Eggs & 80 & 25.8 \\
\hline $\begin{array}{l}\text { Dark leafy green vegetables } \\
\text { Another vitamin A rich fruits and }\end{array}$ & 66 & 56.5 \\
\hline vegetables & 175 & 21.3 \\
\hline Other fruits and vegetables & 188 & 60.64 \\
\hline
\end{tabular}

\section{Health-related characteristics of the study subjects}

Majorities, 299 (96.4\%), of the study participants, were categorized under the WHO clinical stage I, where 226 (72.9\%) of them had CD4 count greater than $350 \mathrm{mg} / \mathrm{dl}$. In addition, about $25(8.1 \%)$ of the study participants have reported opportunistic infection like diarrhea, oral trash, and pulmonary tuberculosis. Finally about 73 (23.5\%), 25 (8\%), and 2 (0.6\%) were underweight, overweight and obese respectively (Table 3 ).

Table 3: Health-related Characteristics of patients on HAART at Public Health Facilities of Ambo town, West Shoa Zone, Ethiopia 2019 $(n=310)$.

\begin{tabular}{|c|c|c|c|}
\hline $\begin{array}{l}\text { Health related } \\
\text { characteristics }\end{array}$ & Category & Frequency & Percent \% \\
\hline \multirow{4}{*}{$\begin{array}{l}\text { WHO clinical } \\
\text { Stage }\end{array}$} & Stage I & 299 & 96.5 \\
\hline & Stage II & 7 & 2.3 \\
\hline & Stage III & 3 & 1 \\
\hline & Stage IV & 1 & 0.3 \\
\hline \multirow[t]{3}{*}{ CD4 Count } & $<200$ cells/microlitre & 21 & 6.8 \\
\hline & $\begin{array}{l}200-350 \quad \text { cells/ } \\
\text { microlitre }\end{array}$ & 63 & 20.3 \\
\hline & $>350$ & 226 & 72.9 \\
\hline \multirow[t]{3}{*}{ BMI } & $<18.5 \mathrm{~kg} / \mathrm{m}^{2}$ & 73 & 23.5 \\
\hline & $18.5-24.9 \mathrm{~kg} / \mathrm{m}^{2}$ & 210 & 67.7 \\
\hline & $25-29.9 \mathrm{~kg} / \mathrm{m}^{2}$ & 24 & 7.7 \\
\hline
\end{tabular}




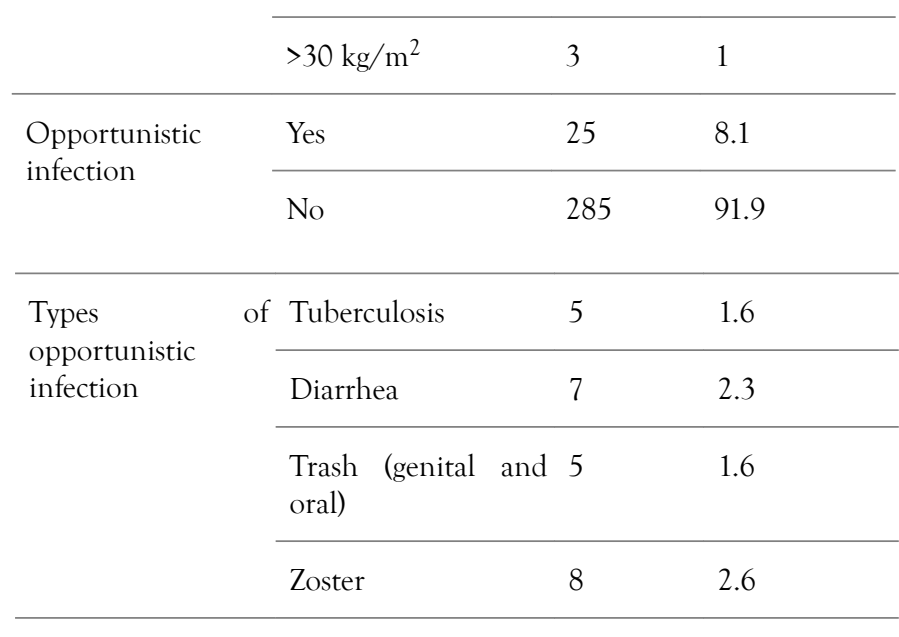

\section{Factors associated with dietary diversity of the study subjects}

Multivariate analysis of this study revealed that Sex (Gender), marital status and Monthly income were significantly associated with Dietary diversity of patients on HAART. It was noticed that HIV positive Males were $57 \%$ less likely to have low dietary diversity than females $(\mathrm{AOR}=0.43)(0.21-0.87)$. Adults those who were separated from their husband/wife were about $68 \%$ less likely to have low dietary diversity than widowed HIV positive adults $(\mathrm{AOR}=0.32$ (0.11-0.88). Furthermore, Monthly income was also seen to be the factors significantly associated with dietary diversity. Those who earn a monthly income of $<1371.13$ Ethiopian birrs were 1.87 times more likely to have low dietary diversity than those who earn $\geq 1371.13$ Ethiopian birrs $(\mathrm{AOR}=1.87$ (1.02-3.44) (Table 4).

Table 4: Factors associated with Dietary Diversity of patients on HAART at Public Health Facilities of Ambo town, West Shoa Zone, Ethiopia 2019 $(n=310)$.

\begin{tabular}{|c|c|c|c|c|c|c|}
\hline \multicolumn{2}{|l|}{ Variables } & \multirow{2}{*}{$\begin{array}{l}\text { Frequency (\%) } \\
109(35.2)\end{array}$} & \multirow{2}{*}{$\begin{array}{l}\text { Non-Optimum } \\
\text { DDS } \\
80\end{array}$} & \multirow{2}{*}{$\begin{array}{l}\text { Optimum } \\
\text { DDS } \\
29\end{array}$} & \multirow{2}{*}{$\begin{array}{l}\text { Crude OR }(95 \% \mathrm{CI}) \\
0.83(0.49-1.4)^{*}\end{array}$} & \multirow{2}{*}{$\begin{array}{l}\text { Adjusted OR }(95 \% \\
\text { CI }) \\
0.43(0.21-0.87)^{* *}\end{array}$} \\
\hline Sex & Male & & & & & \\
\hline & Female & $201(64.8)$ & 140 & 61 & 1 & 1 \\
\hline \multirow[t]{2}{*}{ Family size } & $<5$ & $200(64.5)$ & 137 & 63 & $0.7(0.41-1.19)$ & $1.27(0.67-2.4)$ \\
\hline & $\geq 5$ & $110(35.5)$ & 83 & 27 & 1 & 1 \\
\hline \multirow[t]{2}{*}{ Monthly income } & $<1371.13$ (mean) & $166(53.5)$ & 132 & 34 & $2.47(1.49-4.09)^{*}$ & $1.87(1.02-3.44)^{* *}$ \\
\hline & $\geq 1371.13$ (mean) & $144(46.5)$ & 88 & 56 & 1 & 1 \\
\hline \multirow[t]{2}{*}{ Current residence } & Urban & $235(75.8)$ & 160 & 75 & $1.87(1.00-3.51)^{*}$ & $1.35(0.57-3.19)$ \\
\hline & Rural & $75(24.2)$ & 60 & 15 & 1 & 1 \\
\hline \multirow[t]{4}{*}{ Educational status } & Not read and write & $96(31.0)$ & 86 & 10 & 1 & 1 \\
\hline & Read and write & $66(21.3)$ & 49 & 17 & $2.98(1.26-7.02)^{*}$ & $3.7(1.44-9.59)$ \\
\hline & Primary school & $132(42.9)$ & 80 & 53 & $5.69(2.7-11.96)^{*}$ & $7.65(3.1-18.8)$ \\
\hline & Collage/university & $15(4.8)$ & 5 & 10 & $17.2(4.89-60.48)^{*}$ & $22.5(4.4-115)$ \\
\hline \multirow[t]{4}{*}{ Marital status } & Married & $173(55.8)$ & 131 & 42 & $0.62(0.31-1.24)^{*}$ & $0.43(0.18-1.01)$ \\
\hline & Separated & $60(19.4)$ & 44 & 16 & $0.7(0.3-1.61)^{*}$ & $0.32(0.11-0.88)$ \\
\hline & Single & $30(9.7)$ & 14 & 16 & $2.21(0.86-5.65)^{*}$ & $0.89(0.23-3.35)$ \\
\hline & widowed & $47(15.2)$ & 31 & 16 & 1 & 1 \\
\hline \multirow[t]{2}{*}{ Owner of house } & Rent & $111(18.8)$ & 106 & 35 & 1 & 1 \\
\hline & Self & $284(48.1)$ & 114 & 55 & $0.68(0.41-1.12)^{*}$ & $1.63(0.85-3.11)$ \\
\hline \multirow[t]{2}{*}{ Drink alcohol } & Yes & $13(4.2)$ & 9 & 4 & $1.09(0.32-3.63)^{*}$ & $1.01(0.52-4.32)$ \\
\hline & No & 297 (95.8) & 211 & 86 & 1 & 1 \\
\hline
\end{tabular}




\begin{tabular}{lllllll}
\hline Have a home garden & Yes & $50(16.1)$ & 32 & 18 & $1.46(0.77-2.78)^{*}$ & $1.3(0.57-3.19)$ \\
& No & $260(83.9)$ & 188 & 72 & 1 & 1 \\
\hline CD4 count & 200 & $21(6.8)$ & 19 & 2 & 1 & 1 \\
\hline & $200-350$ & $63(20.3)$ & 41 & 22 & $0.255(0.32-3.63)^{*}$ & $3.77(0.7-20.3)$ \\
\hline Opportunistic infection & Yes & $226(72.9)$ & 160 & 66 & $1.3(0.72-2.35)$ & $2.53(0.50-2.8)$ \\
\hline No & $25(8.1)$ & 17 & 8 & $1.16(0.48-2.8)^{*}$ & $1.97(0.65-5.93)$ \\
\hline BMI & $285(91.9)$ & 203 & 82 & 1 & 1 \\
\hline & 18.5 & $75(24.2)$ & 49 & 26 & 1 & 1 \\
\hline & $204(65.8)$ & 151 & 53 & $0.66(0.37-1.16)^{*}$ & $0.73(0.36-1.48)$ \\
\hline
\end{tabular}

*: p-value $<0.3 ;{ }^{* *}$ : p-value $<0.05$

\section{DISCUSSION}

The analysis of this study found that majorities, 220 (71\%) of the respondents had low dietary diversity score. This finding reported higher prevalence of low dietary diversity score than previous studies conducted in Ethiopia at Dilchora Hospital and Hiwot Fana Hospital with 28.7\%, Metema Hospital with 58.8\%, Butajira Hospital with $38.8 \%$ and Jimma University Specialized Hospital with $55.8 \%$, of the study subjects having low level of dietary diversity score $[14,17-19]$. Similarly, this finding is also higher than studies conducted in other African countries like Uganda and Rwanda with $59 \%$ and $43 \%$, of study participants having low dietary diversity score respectively [20,21]. This indicates the high level of nutrient inadequacy of foods consumed over a given period of time by study subjects in the study area. The variation of the report can be explained by the fact that socio-demographic and agricultural factors differences in the study areas. West Shoa Zone (i.e study area) was among areas identified by FAO as a food deficit zone as well as reported to be an area which has weak cereal and crop marketing chain $[22,23]$.

The result of this study revealed that the most predominantly consumed food groups by the study participants were starchy stables. About 307 (99\%) of the respondents have consumed foods made of grains, roots, and tubers (starchy stables). This finding is similar to previous studies conducted in the country (Ethiopia) [18,19,24]. However, organ meats were the least consumed food groups among the study participants in the study area. Only 41 (13.2\%) of the study participants have reported consumption of organ meats in the last 24 hour prior to data collection. This may be due to unavailability of organ meats and economical problem, as organ meats are more expensive than starchy staples found in the study area.

In this study, a significant association was observed between sex (gender) and dietary diversity score. Males were 57\% less likely to have low dietary diversity than females (AOR=0.43
(0.21-0.87)). This result is in line with known facts that females have more difficulty than men in accessing resources including land, credit, and agricultural commodities reported somewhere else [25,26]. It may be explained further by; females were less likely to be employed and unable to decide in households and therefore couldn't get access to foods that meet their needs.

Monthly income was also other predictors of dietary diversity among the study participants. Those who earn a monthly income of $<1371.13$ Ethiopian birrs were 1.87 times more likely to have low dietary diversity than those who earn $\geq 1371.13$ Ethiopian birrs $(A O R=1.87(1.02-3.44)$. This result is similar to studies conducted at Butajira and Jimma Hospital [17,19]. The reason might be when the income level of an individual decrease the ability to buy sufficient and diversified food will decrease, and then it leads to poor nutrient adequacy of the diet of an individual.

A significant association was also seen between marital status and dietary diversity score. Adults those who were separated from their husband/wife were about $68 \%$ less likely to have low dietary diversity than widowed HIV positive adults ( $A O R=0.32$ (0.11-0.88). This is because due to separation, the number of independents in the household may decrease and therefore when the number of independents in the households decreases there may be access to sufficient diversified diet among the remaining family members as explained somewhere else [20].

\section{CONCLUSION AND RECOMMENDATION}

This study revealed that about $71 \%$ of adults on HAART had low dietary diversity score which indicates severe nutrient inadequacy among the participants. Sex, marital status, and monthly income were among factors associated with dietary diversity score. Therefore the town administration, NGO's working on HIV and other stakeholders should work on empowering females and sustainable income generating projects for HIV patients. 


\section{FUNDING STATEMENT}

There was no funding source for this study.

\section{AUTHORS' CONTRIBUTION}

KT: Conceptualized the paper, searched literature, trained field researchers for data collection and wrote the results and discussion sections; TT, ET and DA: Contributed to the design of the study and provided advice regarding methods, data interpretation and analysis; KT: Also has critically reviewed the result and prepared the manuscript for publication; Finally all authors have proofread the final manuscript.

\section{COMPETING INTERESTS}

The authors declare that they have no competing interests.

\section{ACKNOWLEDGMENT}

It gives us great respect to thank all study participants for their cooperation in providing the necessary information. Our gratitude is great to research assistants who participated in data collection and supervision in this study. Finally, great thank goes to Ambo University and Public health facilities in Ambo Town for logistic support during data collection.

\section{REFERENCES}

1. Maartens G, Celum C, Lewin SR. HIV infection: Epidemiology, pathogenesis, treatment, and prevention. The Lancet. 2014;384:258-271.

2. Piot P, Bartos M, Ghys PD, Walker N, Schwartländer B. The global impact of HIV/AIDS. Nature. 2001;410:968.

3. Slogrove AL, Sohn AH. The global epidemiology of adolescents living with HIV: Time for more granular data to improve adolescent health outcomes. Curr Opin HIV AIDS. 2018;13:170-178.

4. Institute EPH. HIV related estimates and projections for Ethiopia-2017. 2017.

5. Elias N. Federal Democratic Republic of Ethiopia Ministry of Health. Quarterly Health Bulletin. 2014;6.

6. Maertens JA. Barriers to nutrition management among people living with HIV on antiretroviral therapy. Colorado State University. 2011.

7. Anand D, Puri S, Mathew M. Assessment of quality of life of HIVpositive people receiving ART: an Indian perspective. Ind J Community Med. 2012;37:165.

8. Hsu JW, Pencharz PB, Macallan D, Tomkins A. Macronutrients and HIV/AIDS: A review of current evidence. Durban, South Africa: World Health Organization. 2005.

9. Swindale A, Bilinsky P. Household dietary diversity score (HDDS) for measurement of household food access: indicator guide. Washington, DC: Food and Nutrition Technical Assistance Project, Academy for Educational Development. 2006.

10. Ruel MT. Is dietary diversity an indicator of food security or dietary quality? A review of measurement issues and research needs. Food Nut Bull. 2003;24:231-232.
11. Faber M, Schwabe C, Drimie S. Dietary diversity in relation to other household food security indicators. Int J Food Safety Nut Public Health. 2009;2:1-15.

12. Foote JA. Murphy SP, Wilkens LR, Basiotis PP, Carlson A. Dietary variety increases the probability of nutrient adequacy among adults. J Nutr. 2004;134:1779-1785.

13. Mirmiran P, Azadbakht L, Esmaillzadeh A, Azizi F. Dietary diversity score in adolescents-a good indicator of the nutritional adequacy of diets: Tehran lipid and glucose study. Asia Pacific J Clin Nutr. 2004;13.

14. Weldegebreal F, Digaffe T, Mesfin F, Mitiku H. Dietary diversity and associated factors among HIV positive adults attending antiretroviral therapy clinics at Hiwot Fana and Dilchora Hospitals, eastern Ethiopia. HIV/AIDS Auckl. 2018;10:63.

15. Kennedy GL, Pedro MR, Seghieri C, Nantel G, Brouwer I. Dietary diversity score is a useful indicator of micronutrient intake in nonbreast-feeding Filipino children. J Nutr. 2007;137:7.

16. Arimond M, Wiesmann D, Becquey E, Carriquiry A, Daniels MC, Deitchler M, et al. Simple food group diversity indicators predict micronutrient adequacy of women's diets in 5 diverse, resourcepoor settings. J Nutr. 2010;140.

17. Tiyou A, Belachew T, Alemseged F, Biadgilign S. Food insecurity and associated factors among HIV-infected individuals receiving highly active antiretroviral therapy in Jimma zone Southwest Ethiopia. Nutr J. 2012;11:51.

18. Woldemariam AT, Yusuf ME, Beyen TK, Yenit MK. Factors associated with dietary diversity among HIV positive adults $(\geq 18$ years) attending ART clinic at Mettema hospital, Northwest Ethiopia: cross-sectional study. J AIDS Clin Res. 2015;6:490.

19. Gedle D, Mekuria G, Kumera G, Eshete T, Feyera F, Ewunetu T. Food Insecurity and its associated factors among people living with HIV/AIDS receiving anti-retroviral therapy at Butajira hospital, Southern Ethiopia. J Nutr Food Sci. 2015;5:2-6.

20. Bukusuba J, Kikafunda JK, Whitehead RG. Food security status in households of people living with HIV/AIDS (PLWHA) in a Ugandan urban setting. Br J Nutr. 2007;98:211-217.

21. Sirotin N, Hoover D, Segal-Isaacson CJ, Shi Q, Adedimeji A, Mutimura E, et al. Structural determinants of food insufficiency, low dietary diversity and BMI: A cross-sectional study of HIVinfected and HIV-negative Rwandan women. BMJ Open. 2012;2:e000714.

22. FAO W. FAO/WFP crop and food supply assessment mission to Ethiopia. 2009.

23. Solomon A, Teshale J. Surveying of cereal crops market chain in West Shoa Zone of Oromia Regional State, Ethiopia. Int J Res Rev. 2017;6.

24. Tesfaw A, Jara D, Temesgen H. Dietary diversity and associated factors among HIV positive adult patients attending public health facilities in Motta Town, East Gojjam Zone, Northwest EthHindAdv Public Health. 2017;2018:8.

25. FAO. The state of food insecurity in the world: Addressing food insecurity in protracted crises. 2010.

26. Lubbock A, Borquia R. Survival, change and decision-making in rural households: Three village case studies from eastern Morocco. 1998. 